\title{
Speciation of Lead, Iron and Cadmium in Selected Brands of Canned Sardine Fish Sold in Port Harcourt, Rivers State, Nigeria
}

\author{
Ekwere, Ifiok Okon', Verla, Andrew Wirnkor ${ }^{2 *}$, Verla Evelyn Ngozi ${ }^{3}$ Horsfall, Michael Jnr'. \\ ${ }^{1}$ Department of Pure and Industrial Chemistry, University of Port Harcourt, Rivers State, Nigeria \\ ${ }^{2}$ Departments of Chemistry, Imo State University, Owerri, Imo State, Nigeria \\ ${ }^{3}$ Departments of Environmental Technology, FUTO, Owerri, Imo State, Nigeria
}

*Corresponding Author: Verla Andrew Wirnkor, Departments of Chemistry, Imo State University, Owerri, Imo State, Nigeria

\begin{abstract}
Chemical Speciation is a significant factor that governs toxicity and mobility of heavy metals Therefore knowledge of polar and non-polar forms of metals could be useful in predicting toxicity. In this research chemical species of lead, iron and cadmium in selected canned fish marketed in Nigeria were evaluated as polar form of nonpolar concentrations. Dry digestion was carried out on the sardine fish meal while wet digestion was applied to the fish oil. The metal concentration was determined using the Flame Absorption Spectrophotometer. The results show that the concentration of the trace metals in the fish meal and fish oil ranged from $13.12 \pm 3.81(\mathrm{~Pb}), 19.22 \pm 4.83(\mathrm{Fe}), 2.50 \pm 0.48(\mathrm{Cd}) \mathrm{mg} / \mathrm{kg}$ and $14.37 \pm 4.34(\mathrm{~Pb}), 15.54$ $\pm 2.45(\mathrm{Fe}), 1.65 \pm 0.4(\mathrm{Cd}) \mathrm{mg} / \mathrm{kg}$ respectively. Chemical speciation of fish meal and fish oil gave rise to varying amounts of polar and non-polar fractions. The polar fractions of fish meal and fish oil ranged between $0.82 \pm 0.49(\mathrm{~Pb}), 2.0 \pm 0.48(\mathrm{Fe}), 0.27 \pm 0.17(\mathrm{Cd}) \mathrm{mg} / \mathrm{kg}$ and $4.13 \pm 1.47(\mathrm{~Pb}), 5.93 \pm 1.25(\mathrm{Fe}), 0.50 \pm 0.17$ (Cd) $\mathrm{mg} / \mathrm{kg}$ respectively; non polar fractions of fish meal and oil ranged between $2.07 \pm 0.73(\mathrm{~Pb}), 2.23 \pm 0.58$ $(\mathrm{Fe}), 0.36 \pm 0.08(\mathrm{Cd}) \mathrm{mg} / \mathrm{kg}$ and $10.13 \pm 2.94(\mathrm{~Pb}), 8.65 \pm 1.63(\mathrm{Fe}), 1.45 \pm 1.41(\mathrm{Cd}) \mathrm{mg} / \mathrm{kg}$ respectively. Results reveal that the non-polar species of metals were predominant in the canned fish analyzed.
\end{abstract}

Keywords: Digestion, Extraction, Fish meal, Polar, Toxicity.

\section{INTRODUCTION}

Fish contains high protein content, low saturated fat, essential minerals and omega fatty acids that support good health. The total mineral content in the flesh of marine fish ranges from 0.6 to $1.5 \%$ wet weight [1]. In Nigeria, due to the insufficient domestic catches and aquaculture production, there is high dependence on large volumes of imports to satisfy local demand. These imported fishes are mostly frozen or canned fish. Canned fish are fish which have been processed, sealed in airtight container such as a sealed tin can, and subjected to heat. Boadi, et al., [2], stated that canned fish is subjected to lead contamination during canning process. Solder used in the manufacture of cans has been recognized as a source of lead contamination during canning [3]. The $\mathrm{pH}$ of the canned products, oxygen concentration in headspace, quality of coating and storage place may also influence metal levels in canned fish.

Metal toxicity, environmental mobility and tendency to be accumulated in living systems has been directly linked to the metals chemical forms. Knowledge of the total concentration gives only poor information about the potential risk. Thus, the need for speciation analysis arises from the necessity to determine the concentration of those species characterized by the highest toxicity, mobility etc. with respect to the other species of the same element. Metals may be present in an environmental compartment but yet, not bioavailable. Therefore, it is important that speciation of canned fish be periodically carried out [4].

Speciation can also be based on the polarity of the species. Polar species dissolve in polar solvents while non polar species dissolve in non-polar solvents. Generally, inorganic species are said to be polar while organic or organometallic species are said to be non-polar. Knowledge of the distribution of polar and non-polar species of metals in fish will help us to better understand the toxicokinetics of these metals when it enters the human system. For instance, polar species will likely enter the blood plasma and brain fluid while non polar species will be found in the blood lipids $[5,6]$. 
Levels of heavy metals concentration in canned fish has been widely reported and studied [7] Work on the heavy metal contamination in canned fish marketed within Kumasi in the Ashanti region of Ghana for $\mathrm{Pb}, \mathrm{Zn}, \mathrm{Fe}, \mathrm{Cd}, \mathrm{Mn}$ and $\mathrm{Hg}$, reported that the trace metals were within permissible levels in most of the canned fish analyzed [8]. Suhendran [9], stated that trace metals in canned fish must be monitored comprehensively and periodically with respect to the consumer's health. Literatures abound on determination of total amount of heavy metals and not on the speciation of metals. However, Spayad et al., [10], reports that the different species of arsenic produce diverse toxicological effects in human, with inorganic forms being more toxic than organic ones. They stated that the species of arsenic found in fish are arsenobetaine (AsB) and arsenocholine (AsC), which are relatively less toxic to humans compared to the other species.

The aim of this research is therefore to investigate selected trace metals, $\mathrm{Pb}, \mathrm{Cd}$ and $\mathrm{Fe}$ levels in canned fish marketed in Port Harcourt and their speciation as polar and non-polar fractions. The specific objectives is twofold namely; determination of total trace metals in canned fish meal, and fish oil and then determination of the polar and non-polar fractions of the trace metals found in them. The importance of such a study lies in the fact that there are no regulations on the amount of heavy metals in canned fish here in Nigeria.

\section{MATERIALS AND MethodS}

\subsection{Sampling}

The canned fish used in this work were obtained from supermarkets in Port Harcourt, Rivers State, Nigeria. The brands used were Geisha Sardine (G), Titus Sardine (T) and Queens Sardine (Q). Twentyseven canned sardines were grouped into three brands to give nine samples per group, labeled $\mathrm{G} 1(\mathrm{n}=3)$, G2 ( $n=3)$, G3 $(n=3)$, T1 $(n=3)$, T2 $(n=3)$, T3 $(n=3)$, Q1 $(n=3)$, Q2 $(n=3)$, Q3 $(n=3)$. After opening the canned sardines, oil was drained out as a separate set of sample; thus, there were nine samples of sardine fish and nine samples of sardine oil.

\subsection{Sample Storage/Treatment}

The oil sample was stored in a freezer at below $4^{\circ} \mathrm{C}$ while the fish meal sample was weighed and immediately transferred to an oven. It was dried in the oven at $50^{\circ} \mathrm{C}$ until a constant weight was recorded. The dried fish was brought out and homogenized with a mortar and pestle. The dried fish was then stored in an air tight container until extraction and/ or digestion was carried out.

\subsection{Determination of Physicochemical Characteristic of the Sardine Sample}

The $\mathrm{pH}$ and conductivity were determined according to the method of ASTM D3838-80 with slight modification according to method of [11]. One (1.0) g of each sample was weighed and transferred into a $250 \mathrm{ml}$ beaker and $100 \mathrm{ml}$ of distilled water was added and stirred for 1 hour. Samples were allowed to stabilize and then $\mathrm{pH}$ measured using an electronic $\mathrm{pH} /$ Conductivity meter, Jenway 430 Model. The same samples were further used for electrical conductivity (EC) of the fish and results read off in $\mu \mathrm{S}$.

The constant weight of a beaker was obtained and thereafter the whole wet sardine fish sample was weighed into the beaker and transferred to the oven for 4 hrs at $70^{\circ} \mathrm{C}$. The sample was cooled and weighed. This was continued until a constant weight was obtained. Moisture content was estimated thus,

$\%$ Moisture content $=\frac{\left[W_{1}-\left\{W_{3}-W_{2}\right\}\right]}{W_{1}} \times 100$

Where $\mathrm{W}_{1}$ = weight of wet sardine sample, $\mathrm{W}_{2}=$ constant weight of crucible

$\mathrm{W}_{3}=$ weight of sample + beaker after drying and cooling [12]

\subsection{Determination of the Total Metal Content in Sardine Fish Meal}

$2 \mathrm{~g}$ of the dried fish sample was weighed into a $250 \mathrm{~mL}$ conical flask and $15 \mathrm{~mL}$ of concentrated nitric acid was added. The conical flask was covered with a watch glass until most of the sample had dissolved by standing overnight. The solution was heated on a hot plate at about $70^{\circ} \mathrm{C}$ until all the yellowish brown fumes are ended. After cooling, small portions of deionized hot water was added to dissolve the precipitate left. The sample was filtered with No. 541 Whatman filter paper into a $100 \mathrm{~mL}$ beaker. The filtrate was made up to the $100 \mathrm{Ml}$ mark with deionized water and then taken to the AAS for analysis. 
Speciation of Lead, Iron and Cadmium in Selected Brands of Canned Sardine Fish Sold in Port Harcourt, Rivers State, Nigeria

\subsection{Extraction Procedure for Fish Meal}

\subsubsection{Methanol Extraction}

$5 \mathrm{~g}$ of the dried and grounded fish meal was collected in a $100 \mathrm{~mL}$ beaker and $25 \mathrm{~mL}$ of methanol was added and left to stand for $24 \mathrm{hrs}$. After $24 \mathrm{hrs}$, the sample was filtered with Whatman filter No. 541, and the filtrate (methanol extract) was left in the open until digestion was carried out. The methanol extract is the polar fraction of the sample

\subsubsection{Hexane Extraction}

The residue from (a) above was dried to constant weight (to completely remove methanol) and then collected in a fresh $100 \mathrm{~mL}$ beaker. $25 \mathrm{~mL}$ of hexane was added to the residue and left to stand for 24 hrs. Then the sample was filtered and the filtrate (hexane extract) was left in the open until digestion. The hexane extract is the non polar fraction of the sample. The solvent in extract (a) and (b) was not allowed to evaporate to dryness before digestion was carried out [13].

\subsubsection{Digestion of the Fish Meal Extract}

$1 \mathrm{~mL}$ of concentrated nitric acid was added to the extract and heated to a low volume in a beaker, making certain that the sample does not boil and that no portion of the beaker is allowed to go to dryness. The heating continues with small addition of the nitric acid until the digest is light in colour or does not change appearance with continuous heating. Any precipitate formed was dissolved with small quantity of hydrochloric acid. On completion of digestion, small amount of deionized water was added and stirred. The solution was filtered and the final volume of the filtrate was adjusted and stirred. The solution was filtered and the final volume of the filtrate was adjusted to $50 \mathrm{ml}$ with deionized water. The sample was then taken to the AAS for analysis.

\subsection{Determination of the Total Metal Content in the Fish Oil}

The oil sample was removed from the freezer, melted in a water bath at $30^{\circ} \mathrm{C}$ and mixed thoroughly before sampling. Samples were prepared for analysis by wet digestion (acid digestion) as outlined by Anwar et al., [14]. Duplicate samples $1.0 \mathrm{~g}$ was weighed into separate conical flasks. $5 \mathrm{~mL}$ of concentrated nitric acid was then added and the contents heated at $70-80^{\circ} \mathrm{C}$ for $2-3$ hours, on a hot plate. Heating was continued at about $150^{\circ} \mathrm{C}$ overnight, $3-5 \mathrm{~mL}$ of concentrated sulphuric acid and $30 \%$ hydrogen peroxide (each) was added occasionally and continuous heating further allowed to completely the organic matter. All contents of the flask were evaporated and the semi-dried mass was dissolved in a small amount $(5 \mathrm{~mL})$ of deionized water, filtered through Whatmann no. 42 filter paper, and made up to a final volume of $25 \mathrm{~mL}$ in volumetric flask with $2 \mathrm{~N}$ nitric acid.

\subsection{Extraction of Fish Oil}

$1 \mathrm{~g}$ of the sardine fish oil was weighed into a conical flask, then $15 \mathrm{ml}$ each of methanol and hexane was weighed into it. This mixture was shaken together and allowed to stand for $24 \mathrm{hrs}$. it was then transferred into a separating funnel and two layers were formed. The lower layer, which represented the hexane fraction, was separated from the upper layer (methanol fraction). The extracts were kept in an open for $24 \mathrm{hrs}$ to allow some of it to evaporate and to achieve reduction in volume. Then, digestion was carried out and the digestate was made up to $25 \mathrm{ml}$ with distilled water.

\subsection{Instrumentation}

The flame atomic absorption spectrophotometer (FAAS) Buck Scientific Model 205 with acetylene gas was used in the determination of the heavy metals. Concentration of metals was calculated with reference to a standard curve. Calibration of the instrument was done by preparing standard solutions of the metal in concern by diluting their Certified Reference Material (CRM). The standard concentration prepared were $0.1 \mathrm{mg} / \mathrm{l}$ and $0.01 \mathrm{mg} / \mathrm{l}$ for the points to draw the calibration curve. Table 1 shows the instrumental conditions used for the analysis of the sample and standards. 
Speciation of Lead, Iron and Cadmium in Selected Brands of Canned Sardine Fish Sold in Port Harcourt, Rivers State, Nigeria

Table1. Instrumental Conditions used for the Analysis of Samples and Standards

\begin{tabular}{|c|c|c|c|c|c|c|c|}
\hline Metal & $\begin{array}{c}\text { Wavelength } \\
(\mathrm{nm})\end{array}$ & $\begin{array}{c}\text { Slit width } \\
(\mathrm{nm})\end{array}$ & $\begin{array}{c}\text { Lamp } \\
\text { Current(mA) }\end{array}$ & Fuel/Oxidant & $\begin{array}{c}\text { Flame } \\
\text { colour }\end{array}$ & $\begin{array}{c}\text { Detection } \\
\text { limit }\end{array}$ & $\begin{array}{c}\text { Signal } \\
\text { Output }\end{array}$ \\
\hline $\mathrm{Pb}$ & 283.3 & 0.7 & 1.5 & $\begin{array}{c}\text { Acetylene/ } \\
\text { Air }\end{array}$ & $\begin{array}{c}\text { Lean } \\
\text { blue }\end{array}$ & 0.08 & $100 \%$ \\
\hline $\mathrm{Fe}$ & 248.3 & 0.2 & 1.5 & Acetylene/ Air & $\begin{array}{c}\text { Lean } \\
\text { blue }\end{array}$ & 0.05 & $100 \%$ \\
\hline $\mathrm{Cd}$ & 228.9 & 0.7 & 1.5 & & & 0.01 & $100 \%$ \\
\hline
\end{tabular}

\subsection{Analytical Quality Assurance (AQA)}

All glasswares were soaked overnight in $10 \%$ (v/v) nitric acid, followed by washing with $10 \%$ (v/v) hydrochloric acid and rinsed with double deionized water and dried before use. All other quality control measures were carried out according to [15]

\subsection{Statistical Analysis}

Data obtained from this study were analyzed using the statistical package for social sciences (SPSS) version 18.0 for windows. Independent sample t-test was used to compare means, and values were considered significant at $\mathrm{p}<0.05$. Results were reported as mean $\pm \mathrm{n}$ SDV for triplicate analysis where appropriate

\section{RESULTS AND DISCUSSION}

Table2. Physicochemical characteristic of the sardine sample

\begin{tabular}{|c|c|c|c|}
\hline Sample brand & $\mathrm{pH}$ & \% Moisture & Colour \\
\hline TITUS & 5.85 & 63.25 & Brownish \\
\hline GEISHA & 6.2 & 59.69 & Light grey \\
\hline QUEEN & 6.3 & 60.20 & Brownish \\
\hline
\end{tabular}

The $\mathrm{pH}$ value of a canned fish is a direct function of the free hydrogen ions present in it. The $\mathrm{pH}$ recorded for the various type canned fish ranged from 5.85 to 6.60 (Table 2) and are classified as of low-acid foods with a $\mathrm{pH}$ value greater than 4.6.

The moisture content of the fish samples which, in some samples, was as high as $60 \%$. The moisture loss, recorded after drying the sample, will therefore not guarantee an efficient toxicological analysis of the sample when the standard limit used is on a wet weight basis

Table3. Percentage extraction of the metals in the fish meal (\%)

\begin{tabular}{|c|c|c|c|}
\hline Sample ID & Pb & Fe & Cd \\
\hline T 1 & 20 & 23.2 & 30 \\
\hline T 2 & 15 & 18.4 & 26.7 \\
\hline T 3 & 32 & 24.7 & 20 \\
\hline G 1 & 20 & 22.6 & 26 \\
\hline G 2 & 25 & 21.7 & 24 \\
\hline G 3 1 & 28.2 & 34 & 24 \\
\hline Q 2 & 14.7 & 18 & 22.8 \\
\hline Q 3 & 14.8 & 7.8 & 23.6 \\
\hline
\end{tabular}

Key:

T1,T2,T3: \#1,\#2,\#3 Titus sardine fish meal samples respectively

G1,G2,G3: \#1,\#2,\#3 Geisha sardine fish meal samples respectively

Q1,Q2,Q3:\#1,\#2,\#3 Queen sardine fish meal samples respectively

The extraction efficiency of sardine fish range of $7.8 \%$ to $36 \%$ recorded here are low and it implies that most of the metals in the fish are not leachable, thus, are locked in the fish matrix and are found in the residue after extraction. However, the extraction of the fish oil is more efficient with the solvent used; recording almost $100 \%$ extraction in most cases since no residue was left over. 
Speciation of Lead, Iron and Cadmium in Selected Brands of Canned Sardine Fish Sold in Port Harcourt, Rivers State, Nigeria

Table4. Mean trace metal concentration $(\mathrm{mg} / \mathrm{kg})$ in polar $(P F)$ and non polar (NPF) fractions

\begin{tabular}{|c|c|c|c|}
\hline Sample & $\begin{array}{c}\text { Pb } \\
\text { Range (mean } \pm \text { S.E) }\end{array}$ & $\begin{array}{c}\text { Fe } \\
\text { Range }(\text { mean } \pm \text { S.E) }\end{array}$ & $\begin{array}{c}\text { Cd } \\
\text { Range (mean } \pm \text { S.E) }\end{array}$ \\
\hline & & & \\
FISH MEAL & & & \\
TITUS (PF) & $0.4-2.3(1.03 \pm 0.63)$ & $1.2-3.4(2.1 \pm 0.66)$ & $0.2-0.3(0.23 \pm 0.34)$ \\
TITUS (NPF) & $1.7-7.6(3.8 \pm 1.91)$ & $0.4-3.4(2.0 \pm 0.87)$ & $0.1-0.5(0.37 \pm 0.13)$ \\
GEISHA (PF) & $0.5-1.3(0.8 \pm 0.24)$ & $1.7-3.6(2.5 \pm 0.56)$ & $0.2-0.4(0.3 \pm 0.06)$ \\
GEISHA (NPF) & $1.0-1.8(1.33 \pm 0.24)$ & $2.8-4.1(3.43 \pm 0.38)$ & $0.3-0.5(0.4 \pm 0.06)$ \\
QUEENS (PF) & $0.03-1.8(0.62 \pm 0.59)$ & $0.6-1.9(1.4 \pm 0.41)$ & $0.1-0.5(0.27 \pm 0.12)$ \\
\hline QUEENS (NPF) & $1.03-1.17(1.09 \pm 0.04)$ & $0.1-2.3(1.27 \pm 0.56)$ & $0.2-0.4(0.3 \pm 0.06)$ \\
\hline FISH OIL & & & \\
\hline TITUS (PF) & $1.2-2.07(1.58 \pm 0.26)$ & $1.4-3.10(2.41 \pm 0.52)$ & $0.13-0.61(0.38 \pm 0.14)$ \\
\hline TITUS (NPF) & $8.41-21.7(15.16 \pm 3.86)$ & $4.30-9.52(6.39 \pm 1.60)$ & $0.2-1.30(6.39 \pm 3.97)$ \\
\hline GEISHA (PF) & $1.98-4.41(3.45 \pm 0.75)$ & $8.05-15.53(10.56 \pm 2.49)$ & $0.5-0.63(0.54 \pm 0.04)$ \\
\hline GEISHA (NPF) & $4.02-9.65(6.62 \pm 1.63)$ & $8.38-17.30(11.96 \pm 2.73)$ & $1.0-1.3(1.13 \pm 0.09)$ \\
\hline QUEENS (PF) & $1.20-10.69(7.37 \pm 3.41)$ & $3.71-6.20(4.82 \pm 0.73)$ & $0.2-1.25(0.58 \pm 0.33)$ \\
\hline QUEENS (NPF) & $2.10-13.06(8.60 \pm 3.33)$ & $7.08-8.42(7.61 \pm 0.55)$ & $0.5-1.0(0.83 \pm 0.17)$ \\
\hline
\end{tabular}

$P F$ - polar fraction, NPF - non polar fraction

Table5. Mean trace metal concentration $(\mathrm{mg} / \mathrm{kg})$ in the fish meal and oil

\begin{tabular}{|c|c|c|c|}
\hline Sample & Pb (mean \pm S.E) & Fe $($ mean \pm S.E $)$ & Cd $($ mean \pm S.E) \\
\hline TITUS Fish meal & $19.0 \pm 5.77$ & $18.50 \pm 5.20$ & $2.0 \pm 0.58$ \\
\hline Fish Oil & $17.68 \pm 3.99$ & $9.38 \pm 1.54$ & $1.35 \pm 0.52$ \\
\hline GEISHA Fish meal & $8.60 \pm 1.94$ & $24.17 \pm 5.50$ & $3.0 \pm 0.29$ \\
\hline Fish Oil & $10.85 \pm 2.68$ & $23.55 \pm 4.88$ & $1.92 \pm 0.25$ \\
\hline QUEEN Fish meal & $11.72 \pm 3.73$ & $15.0 \pm 3.79$ & $2.5 \pm 0.58$ \\
\hline Fish Oil & $14.57 \pm 6.36$ & $13.68 \pm 0.94$ & $1.67 \pm 0.44$ \\
\hline
\end{tabular}

\subsection{Metals in Fish Meal and Fish Oil}

Figure 1, shows that the total lead concentration in the fish meal ranges from the lowest value of 7.5 $\mathrm{mg} / \mathrm{kg}$ in sample $\mathrm{G} 1$ and $\mathrm{G} 2$ to the highest value of $30.5 \mathrm{mg} / \mathrm{kg}$ in sample $\mathrm{T} 3$. Fe concentration ranged from $9 \mathrm{mg} / \mathrm{kg}$ in Q2 to $34 \mathrm{mg} / \mathrm{kg}$ in $\mathrm{G} 1$, while the Cd concentration ranges from $1 \mathrm{mg} / \mathrm{kg}$ in $\mathrm{T} 1$ to 3.5 $\mathrm{mg} / \mathrm{kg}$ in $\mathrm{G} 1$ and Q3. Generally, the total concentration of $\mathrm{Pb}$ and $\mathrm{Cd}$ reported in this work is found to be higher than the levels reported by Suhendran $[15,16]$.

Figure1 also shows the trace heavy metal concentration in the fish oil of the canned sardine. The concentration range of $\mathrm{Pb}$ was found to be from $3.75 \mathrm{mg} / \mathrm{kg}$ to $25.75 \mathrm{mg} / \mathrm{kg}$; Fe: $7.0 \mathrm{mg} / \mathrm{kg}$ to $33 \mathrm{mg} / \mathrm{kg}$ and $\mathrm{Cd}: 0.5 \mathrm{mg} / \mathrm{kg}$ to $2.5 \mathrm{mg} / \mathrm{kg}$. When compared with each other the metal concentration in fish meals were generally higher than in the oils except for fish oil of GEISHA and QUEEN sardine in which $\mathrm{Pb}$ was significantly higher.

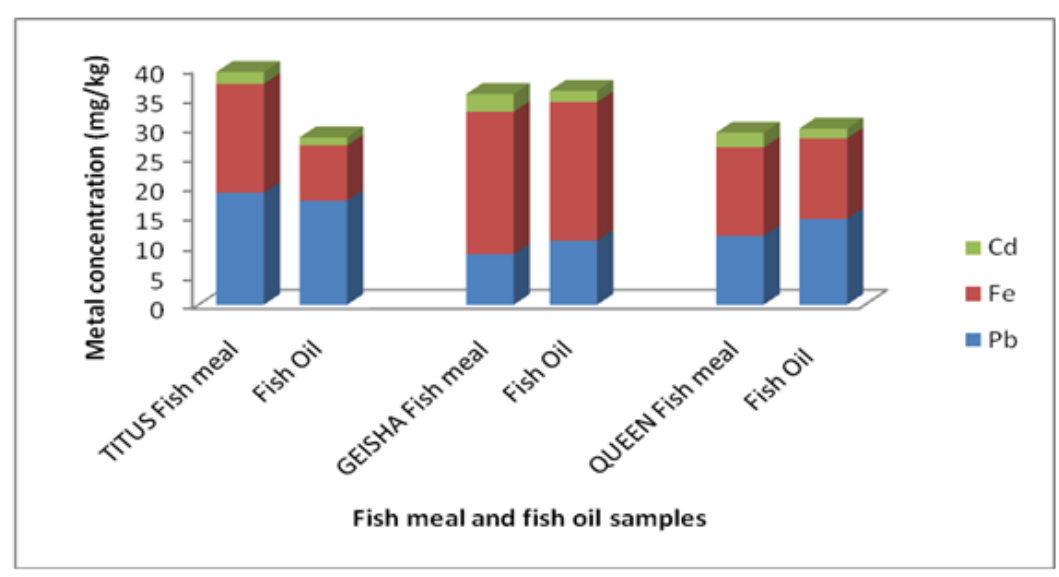

Figure1. Bar plot of Mean trace metal concentration $(\mathrm{mg} / \mathrm{kg})$ in the fish meal and oil 


\subsection{Extraction Efficiency}

The extraction efficiency of the solvents used in this work is represented by the percentage extraction as shown in Table 3, which gives percentage extraction range of 7.8\% of Fe in Q2 to 35\% of Cd in T2 of the dried fish sample. This low extraction efficiency, is likely due to the inability of the solvent to extract most of the metals from the fish tissue. These metals are bound with some proteins in the fish tissue by forming complexes with them; an example is metallothioneins in animal tissue. Metallothioneins are cystein-rich metal binding proteins involved in the detoxification of metals and metabolism of essential metals, and are found in various organs of animals. However, these bound metals can be effectively released by digesting the fish tissue. On the other hand, the solvent extraction of the canned fish oil was found to be more efficient than the fish meal [17].

The extraction efficiency may also have been influenced by the choice of solvent used. However, careful considerations were given before the choice of hexane and methanol as the solvents used. Hexane is a non-polar solvent with a boiling point of $69^{\circ} \mathrm{C}$; dielectric constant of 1.88 ; density, $0.655 \mathrm{~g} / \mathrm{ml}$ and dipole moment, $0.00 \mathrm{D}$. Methanol, on the other hand, is a polar protic solvent with a boiling point of $65^{\circ} \mathrm{C}$; dielectric constant, 33; density, $0.791 \mathrm{~g} / \mathrm{ml}$ and dipole moment of $1.70 \mathrm{D}$. Other considerations bordered on safety issues which include toxicity, flammability, radioactivity.

\subsection{Lead}

The mean concentration of lead in the polar and non-polar fraction of the canned fish samples are presented in Table 4; lead concentration in the polar fraction ranged from $0.62 \mathrm{mg} / \mathrm{kg}$ in QUEEN fish meal to 7.37 in QUEEN fish oil. Meanwhile, lead concentration in the non-polar fraction ranged from $1.09 \mathrm{mg} / \mathrm{kg}$ in QUEEN fish meal to $15.10 \mathrm{mg} / \mathrm{kg}$ in TITUS fish oil. From table 4, the total mean concentration of lead in the fish meal of the various brands, TITUS, GEISHA and QUEEN is given as $19 \mathrm{mg} / \mathrm{kg}, 8.6 \mathrm{mg} / \mathrm{kg}$ and $11.72 \mathrm{mg} / \mathrm{kg}$ respectively; this represents an order of TITUS > QUEEN > GEISHA. Extraction efficiency of lead ranges from 14.1\% (Q1) - 32\% (T3). Also, from table 4, the mean concentration of lead in the sardine fish oil of the various brands, TITUS, GEISHA and QUEEN is given as $17.68 \mathrm{mg} / \mathrm{kg}, 10.85 \mathrm{mg} / \mathrm{kg}$ and $14.57 \mathrm{mg} / \mathrm{kg}$ respectively; representing a concentration order of TITUS > QUEEN > GEISHA.

Generally, it was observed that the lead concentration in the non-polar fractions were higher than the polar fractions. This implies that most of the species of lead found in the sardine fish meal sample were organic or non-polar in nature, while the inorganic or polar lead species were limited. Also, QUEEN sardine fish meal extract had the lowest lead concentration, although it recorded higher concentration in its fish oil. The total metal concentration of lead in canned fish and oil reported in this work is found to be higher than the levels reported by may researcher [18]. Also, the lead concentration in this work is higher than the [19] standard of $0.3 \mathrm{mg} / \mathrm{kg}$ and [20] standard of $2.0 \mathrm{mg} / \mathrm{kg}$ in fish. However, these standard values are based on the wet weight of fish but this work was based on the dry weight of fish, due to the extraction necessity. According to the [20] the legal limit of lead in dried fish in the United Kingdom is $5.0 \mathrm{ppm}$. The lead concentration of sardine fish and oil obtained in this work still falls short of this value, thus there seem to be a small degree of contamination, though verification with a dry weight based standard is necessary.

$\mathrm{FAO/} \mathrm{WHO,} \mathrm{[22]} \mathrm{stated} \mathrm{that,} \mathrm{inorganic} \mathrm{lead} \mathrm{compounds} \mathrm{are} \mathrm{classified} \mathrm{by} \mathrm{the} \mathrm{IARC} \mathrm{as} \mathrm{probably}$ carcinogenic to humans. Thus consumption of contaminated fish poses a risk to the consumer. Also, organic lead species like tetraethyl lead, which is toxic to humans, is likely to be found in the fish sample analyzed.

\subsection{Iron}

The range of total iron concentration in the different brands of sardine fish meal was $9 \mathrm{mg} / \mathrm{kg}-34$ $\mathrm{mg} / \mathrm{kg}$, the lowest concentration found in Q2 whereas the highest concentration was found in G1. The total mean concentration of iron in the sardine fish meal of the various brands, TITUS, GEISHA and QUEEN was $18.50 \mathrm{mg} / \mathrm{kg}, 19.65 \mathrm{mg} / \mathrm{kg}$ and $15.0 \mathrm{mg} / \mathrm{kg}$ respectively; thus an iron concentration order of GEISHA > TITUS > QUEEN could be observed. The mean concentration of Fe in the polar fraction of fish meal ranged from $1.4 \mathrm{mg} / \mathrm{kg}$ in (QUEEN) to $2.5 \mathrm{mg} / \mathrm{kg}$ (GEISHA) while the iron concentration in the non-polar fraction ranged from $1.27 \mathrm{mg} / \mathrm{kg}$ (QUEEN) to $3.43 \mathrm{mg} / \mathrm{kg}$ (GEISHA). The total mean concentration of $\mathrm{Fe}$ in the sardine fish oil of the various brands, TITUS, GEISHA and QUEEN was 
Speciation of Lead, Iron and Cadmium in Selected Brands of Canned Sardine Fish Sold in Port Harcourt, Rivers State, Nigeria

$9.38 \mathrm{mg} / \mathrm{kg}, 23.55 \mathrm{mg} / \mathrm{kg}$ and $13.68 \mathrm{mg} / \mathrm{kg}$ respectively; thus, an iron concentration order of GEISHA $>$ QUEEN > TITUS.

The polar fraction of the fish oil recorded an iron concentration range of $2.41 \mathrm{mg} / \mathrm{kg}$ (TITUS) to 10.56 $\mathrm{mg} / \mathrm{kg}$ (GEISHA), whereas non-polar fraction range was $6.39 \mathrm{mg} / \mathrm{kg}$ (TITUS) to $11.96 \mathrm{mg} / \mathrm{kg}$ (GEISHA). From table 5, the extraction efficiency range is $7.8 \%$ (Q2) to $34.0 \%$ (G3). Unlike lead, it was observed that the iron concentration in the polar and non-polar fractions was more evenly distributed, though significantly higher in the non-polar fraction. This implies that there is an almost equal distribution of polar and non polar species in the fish sample. The total Fe concentration was found to be generally lower than the range reported by [23], $11.27-107.17 \mathrm{mg} / \mathrm{kg}$. The observed values of iron level exceeded the WHO and FEPA recommended standards limits of $0.5 \mathrm{mg} / \mathrm{kg}$ in fish food. However, some of the values of iron level were within the limit of $15 \mathrm{mg} / \mathrm{kg}$ as proposed by the Turkish Ministry of Agriculture [24].

\subsection{Cadmium}

The concentration of cadmium was generally lower in all the analyzed samples compared to the concentrations of lead and iron. The range of total cadmium concentration in the different brands of sardine fish meal was $1.0 \mathrm{mg} / \mathrm{kg}-3.5 \mathrm{mg} / \mathrm{kg}$, the lowest concentration found in Q2 while the highest concentration was found in Q3 and G1. The total mean concentration of cadmium in the sardine fish meal of the various brands, TITUS, GEISHA and QUEEN is given as $2.0 \mathrm{mg} / \mathrm{kg}, 3.0 \mathrm{mg} / \mathrm{kg}$ and $2.5 \mathrm{mg} / \mathrm{kg}$ respectively; thus, a cadmium concentration order of GEISHA > QUEEN > TITUS. The cadmium concentration in the polar fraction of fish meal ranged from $0.23 \mathrm{mg} / \mathrm{kg}$ (TITUS) to 0.30 $\mathrm{mg} / \mathrm{kg}$ (GEISHA) whereas the cadmium concentration in the non-polar fraction of fish meal ranged from $0.3 \mathrm{mg} / \mathrm{kg}$ in (QUEEN) to $0.4 \mathrm{mg} / \mathrm{kg}$ in (GEISHA). From Table 5, the extraction efficiency of cadmium in the fish sample ranged from $20 \%$ (G1 \& Q2) to 35\% (T2). The total mean concentration of cadmium in the sardine fish oil of the various brands, TITUS, GEISHA and QUEEN is given a 1.35 $\mathrm{mg} / \mathrm{kg}, 1.92 \mathrm{mg} / \mathrm{kg}$ and $1.67 \mathrm{mg} / \mathrm{kg}$ respectively; an order of GEISHA > QUEEN > TITUS. The polar fraction of the fish oil recorded a cadmium concentration range of $0.38 \mathrm{mg} / \mathrm{kg}$ (TITUS) $-0.58 \mathrm{mg} / \mathrm{kg}$ (QUEEN), while non-polar fraction range was $0.83 \mathrm{mg} / \mathrm{kg}$ (QUEEN) - $6.39 \mathrm{mg} / \mathrm{kg}$ (TITUS). The concentration of cadmium was higher in the non-polar fraction than polar fraction, implying that there are more organic compounds of cadmium than inorganic compounds in the samples analyzed. Some of the cadmium concentrations were found to exceed the recommended EU limit of $0.1 \mathrm{mg} / \mathrm{kg}$ and 0.5 $\mathrm{mg} / \mathrm{kg}$. The high values of total trace metal concentration in this study can be attributed to two factors. First, a relatively higher level of contamination of the sardine fishes may have been used in this study. The source of contamination could be from the fish source water or from the canning process and storage [25]. The $\mathrm{pH}$ of the canned products, oxygen concentration in the head space, quality of coating and storage place may also control metal levels in canned fishes. Generally a lower $\mathrm{pH}$ leads to more availability of metals through leaching from the metal can material or from other sources. Also, has reported that solder used in the manufacture of cans has been recognized as a source of lead contamination during canning [26].

Secondly, the nature of the sample used in the metal analysis could account for the differences in metal concentration. The reference journals/ work listed above used wet fish sample, thus, the metal concentration calculations were on a wet weight basis. Also, most of the standard limits quoted here are based on wet weight. In contrast, the fish samples in this work were dried before digestion and analysis. The drying was necessary to concentrate the metals in the fish and also aid in the efficient extraction of the fish samples with the polar and non-polar solvents.

\section{CONClusion}

Some of the metal concentration observed in this work exceeded the recommended limits, but an effective toxicological analysis cannot be concluded due to the absence of standard limit values based on dry weight for correlation. However, there is an obvious contamination of the sardine samples with heavy metals, especially lead. Metal concentration in the non-polar fraction was generally higher than in the polar fraction, although, iron is slightly evenly distributed. This implies that the commonly found metal species in sardine fish and oil is organic in nature. This knowledge is significant because the distribution and absorption of metals in the human body is somewhat dependent on their polarity. It is 
Speciation of Lead, Iron and Cadmium in Selected Brands of Canned Sardine Fish Sold in Port Harcourt, Rivers State, Nigeria

therefore recommended that in depth work be carried to compile data for metal contents of canned fished to be used in setting up regulatory standards here in Nigeria.

\section{REFERENCES}

[1] El-Sikaily A; El-Said, GF An Intern. Journal, 2010, 16, 6, 1278 - 1294.

[2] Boadi N O; Twumasi SK; Badu M; Osei I Am. J. Sci. Ind. Res., 2011, 2 6,877 - 882.

[3] MAFF (1995). Monitoring and Surveillance of Non-radioactive Contaminants in the Aquatic Environment and Activities Regulating the Disposal of Waste at Sea. Aquatic Environment Monitoring Report No. 44. Directorate of Fisheries Research, Lowestoft.

[4] Horsfall M (Jnr.); Spiff AI, Eur. J. Sci. Res., 2005, 6, 3, 20-36.

[5] Suhendran, M . Journal of Food Comp. and Anal. 2010. 24: (1) 1 - 5.

[6] Islam MM; Bang S; Kim K; Ahmed MK; Jannar M. J. Sci. Res. 2010. 2 ,3, 549-557.

[7] USEPA (2012). Human Health Risk Assessment. http://www.epa.gov/risk/health-risk.htm

[8] Okoye COB; Verla AW. Bio-Research. 2006. 4, 2, 113-115.

[9] Adeniyi AA. Environ. Int. 1996. 22, 259 - 262.

[10] Spayad SE; Robson MG; Xie R; Buckley BT. Human and Ecol. Risk Assess. 2012.18, 5, 1014 - 1035.

[11] Verla AW; Verla EN; Adowei P; Briggs A; Horsfall M Jnr. International Letters of Chemistry, Physics and Astronomy. 2014.14, 2, 179-189.

[12] Verla AW; Verla E N; Adowei P; Briggs A; Awa E; Horsfall M Jnr;. Spiff A I. Merit Research Journal of Environmental Science and Toxicology. 2014. 2, 4, 064-070.

[13] Anwar F; Kazi TG; Saleem R; Bhanger MI. Grasas y Aceites, 2004. 55, 2, 160 - 168.

[14] WHO (1978). Environmental Health Criteria 6: Principles and Methods for Evaluating the Toxicity of Chemicals. WHO, Geneva.

[15] Shiber JG. Mar. Pol. Bul., 2011. doi:10.1016/j.marpolbul.2010.09.008. 1-4

[16] Williams PL; James RC; Roberts SM. Principles of Toxicology: Environmental and Industrial Applications ( $2^{\text {nd }}$ ed.), John Wiley and Sons, Inc. N.Y. 2000. 325 - 374.

[17] Jarosinska D; Biesiada M; Miszynska-Grace M. Science of the Total Enviroment. 2006. 367, 71-78.

[18] Wang X; Sato T; Xing B; Tao S. Sci Total Environ. 2005. 350, 28-37.

[19] WHO. Food Safety Issues Associated with Products from Aquaculture: A Report of a Joint JAV/NACA/WHO Study Group. WHO Technical Report Series 8831999.

[20] USDA. GAIN Report 2012- Exporter Guide on Assessment of Comodity and Trade Issues in Nigeria; prepared by Nzeka, Uche M. 11/20/2012 2012.

[21] FAO/WHO. Report of the $16^{\text {th }}$ Session of the FAO/WHO Coordinating Committee for Africa, ALINORM 05/28/28. 2005.

[22] FAO. Preservation Techniques. Fisheries and Aquaculture Department, Rome. 2005.

[23] FAO. Compilation of Legal Limits for Hazardous Substances in Fish and Fishery Products, FAO Circular 1983. 464, $5-100$.

[24] Republic of Turkey Ministry of Agriculture No 2002/63, Official Gazette: 2002. 23.09.2002-24885.

[25] NRC (National Research Council). Recommended Dietary Allowance (10 ${ }^{\text {th }}$ Ed.), National Academy Press, Washington D.C. 1989.

[26] Verla EN. Heavy Metal Pollution of Residecial and commercial areas from PortHarcourt. An unpublished M.Sc. Dissertation, Department of chemistry, Micheal Okpara University of Agriculture , Umaudike ,Umuahia, Abia State Nigeria. 2007.

Citation: Verla Andrew Wirnkor, et.al, "Speciation of Lead, Iron and Cadmium in Selected Brands of Canned Sardine Fish Sold in Port Harcourt, Rivers State, Nigeria”, International Journal of Advanced Research in Chemical Science, 7(7), pp. 40-47. DOI: https:// doi.org/10.20431/2349-0403.0707005

Copyright: () 2020 Authors, this is an open-access article distributed under the terms of the Creative Commons Attribution License, which permits unrestricted use, distribution, and reproduction in any medium, provided the original author and source are credited. 